RESEARCH ARTICLE

\title{
Comparative Analysis of Rainfall Occurrence and Groundwater Level Fluctuations in Theni District of Tamil Nadu
}

\author{
Ponnuchakkammal $\mathbf{P}^{* 1}$, Ramachandran $\mathrm{J}^{2}$ and Raviraj $\mathbf{A}^{2}$ \\ ${ }^{1}$ Department of Soil and Water Conservation Engineering, Tamil Nadu Agricultural University, Coimbatore-641 003. \\ ${ }^{2}$ Water Technology Centre, Tamil Nadu Agricultural University, Coimbatore-641 003.
}

Received : $17^{\text {th }}$ November, 2019

Revised : $21^{\text {st }}$ January, 2020

Accepted : $15^{\text {th }}$ February, 2020

\begin{abstract}
Groundwater is the primary source for drinking, irrigation, and industrial purposes. Groundwater provides about 24 per cent of global water supply. Groundwater level fluctuates depending on the groundwater recharge and discharge from the aquifer. The climate change, changing rainfall pattern and growing water demand lead to the groundwater level variation year by year. Rainfall is the major source for groundwater recharge. As rainfall increases, groundwater level also increases. Theni District also called Cardamom city located in the foot of Western Ghats is chosen as the study area. The major source of irrigation was well. For analysis of groundwater level status, the Average - Ground Water Level data and Categorization of the firkas in Theni district was collected from State Ground and Surface Water Resources Data Center. Arithmetic averages of Rainfall of stations under the Theni district was collected from India Meteorological Department. Groundwater level rise and fall analysis of Average-Groundwater level data (2011 to 2019) was carried out using the line chart. Comparative analysis was done using Rainfall data Vs Average - Groundwater level data (2014-2018). Considering the last five years, the groundwater level in Theni District has increased. The statistical correlation between the rainfall and groundwater level fluctuation was poor. Categorization of firkas was used as a performance indicator. It was observed that the Safe Firkas increased from 18\% to $41 \%$ and the Critical Firkas increased from $6 \%$ to $12 \%$. In Periyakulam and Theni Taluk there is no change in Firkas category and remains the same as on 2011. This helps in focusing groundwater development in those taluks which are in the fringe of groundwater status.
\end{abstract}

Keywords: Groundwater, Theni district, Over Exploited Firkas, Rainfall.

\section{INTRODUCTION}

Groundwater is a hidden source. It is that part of the water below the earth's surface, which flows naturally out of the Earth's surface. Most of the groundwater is derived from precipitation. Groundwater recharged from atmospheric precipitation is called "meteoric water". Groundwater is an annually replenishable resource, but its availability is nonuniform in space and time. Most of the Earth's liquid fresh water is stored as groundwater. Groundwater provides about 24 per cent of the global water supply. According to Chow et al., (1988), 30.1\% of the freshwater exists as groundwater in the hydrosphere. The water coming through rainfall is not completely flowing as runoff, while some part of it is going as groundwater recharge (Saraf et al., 2004). In the presence of interconnected fractures, cracks, joints, crushed zones (such as faults zones or shear zones), or solution cavities, rainwater can easily percolate through them and contribute to groundwater (Todd, 1980).

The demand for water increases day by day due to the growing population, urbanization, and better standard of living etc, So groundwater plays a significant role in fulfilling the growing demand for different purposes like drinking, irrigation, and industries. Groundwater level fluctuates depending on the groundwater recharge and discharges from the aquifer. Quantification of the rate of groundwater recharge is a necessary prerequisite for efficient groundwater resource management (Sophocleous, 1991). The lowering of groundwater levels has resulted in a reduction in individual well yield, growth in well population, failure of bore wells, drying up of dug wells, and an increase in power consumption (Imtiyaz and Rao 2008). Meteorological and agricultural droughts have an impact on precipitation

$$
107|1-3| 92
$$


and soil moisture respectively (Kokilavani et al., 2019).

Knowledge of water table depth is a crucial element in many hydrological investigations, including agricultural salinity management, landfill characterization, chemical seepage movement, and water supply studies (Buchanan and Triantafilis, 2009). The annual replenishable groundwater resource for the entire country is 433 billion cubic metre (bcm). National Water Policy, 2002 of India stresses that "exploitation of groundwater resources should be so regulated as not to exceed the recharging possibilities, as also to ensure social equity'. In the peninsular states of Andhra Pradesh, Gujarat, Karnataka, Kerala, Madhya Pradesh, Maharashtra, and Tamil Nadu, the general scarcity of sustainable water supply has led to over-stress on the groundwater regime (Chatterjee and Purohit, (2009). In Tamil Nadu, about $63 \%$ of available groundwater resources are now being used. According to State of Environment Report for Tamil Nadu, Owing to a poor monsoon during 2012-13, significant declines in groundwater level was witnessed by districts such as Kanniyakumari, Coimbatore, Karur, Tiruchirappalli, Sivagangai, Dharmapuri, Namakkal, Virudhunagar, Madurai, Dindigul, Salem, Theni, Tiruppur, and Perambalur. So the study on groundwater level became important for reducing demand and supply gap.

With this conceptual enlightenment about groundwater utilization and regulation, a study was taken in the Theni district of Tamil Nadu to analyze the Groundwater level of the district over the years and to study the relationship between the occurrence of Rainfall and fluctuation in the Groundwater Level.

\section{MATERIAL AND METHODS}

\section{Study Area}

The study was taken up in the Theni District, which has an agricultural background and located in the foot of Western Ghats. The primary irrigation source is wells followed by canals and tanks. The geographical location of Theni District is shown in Figure 1.

Theni district, also called cardamom city, is a district of Tamil Nadu state in South India. The geographical extent of Theni district is $3,24,230$ hectares or $3,242.30 \mathrm{sq} . \mathrm{km}$. For administrative purposes, the district has been bifurcated into 5 Taluks, 8 Blocks, and 17 Firkas. Normal Rainfall of the Theni District is $829.8 \mathrm{~mm}$. The mean daily maximum and minimum temperatures observed at Madurai IMD station are $37.5^{\circ} \mathrm{C}$ during May and $20.9^{\circ} \mathrm{C}$ during January. In general, the humidity is high and is highest during November. The relative humidity in the catchment ranges from 37 to 75 per cent. Winds are generally light to moderate with some strengthening in monsoon season. The net irrigated area, is 55718 hectares. Paddy, Cereals, millets, oilseeds, Sugarcane, Cotton, are mainly cultivated in the Theni district. Coconut, Grapes, Mango, Cashew, Silk cotton, Guava, Banana, and Coffee are some of the principle plantation and horticulture crops.

Theni district is bordered by the Kerala State on the west, Madurai district in the east. Dindigul district in the north and Kerala and Virudhunagar district in the south. The district is part of the composite cape comerin to the Cauvery basin and a part of vaigai sub-basin. Vaigai river has its origin in the eastern slope of the Western Ghats at Gandamanayakanur. Suruliar, Theniar, Varahanadhi, and Manjalar are its main tributaries.

\section{Data collection}

For analysis of groundwater level status, the Average -Ground Water Level Status in meters Below Ground Level monthly data and Categorization of the firkas in Theni district as over- Exploited, Critical, Semi critical, Safe and Saline firkas for groundwater development was collected from State Ground and Surface Water Resources Data Center, Water Resources Department, Government of Tamil Nadu. The categorization of firkas of Theni district is shown in (Table 1).

Arithmetic averages of Rainfall (in millimetre) of stations under the Theni district were collected from Customized Rainfall Information System (CRIS), Hydromet Division, India Meteorological Department, Ministry of Earth Sciences, Government of India.

\section{Methodology}

Groundwater level rise and fall analysis of Average-Groundwater level data (2011 to 2019 August) were carried out using the line chart. Comparative analysis was done using Rainfall data Vs. Average - Groundwater level data (2014-2018).

The categorisation of firkas was considered as a performance indicator of the groundwater development. There are five categorization based on the stage of groundwater extraction. Groundwater extraction is more than $100 \%$ is an Over Exploited Firka, $90-100 \%$ is a Critical Firka, $70-90 \%$ is a Semi Critical Firka, less than $70 \%$ is a Safe Firka, and another one is Saline or Poor Quality Firka. Statistical correlation between rainfall and groundwater level fluctuation ware done.

\section{RESULTS AND DISCUSSION}

\section{Average Groundwater Level Analysis}

Figure 2 explains the Average groundwater level from 2011 to 2014 and shows a decreasing 
trend of approximately 5 to 16 mts below ground level in the January month of the year. After that, it increases in 2015 and 2016. When January 2014 and 2019 were compared, the result increased in the groundwater level from approximately 15 to $8 \mathrm{~m}$ below ground level.

Table 1. Categorization of firkas

\begin{tabular}{lrr}
\hline Categorization & \multicolumn{2}{c}{ Number of Firkas } \\
& $\mathbf{2 0 1 1}$ & $\mathbf{2 0 1 3}$ \\
\hline Over Exploited & 5 & 4 \\
Critical & 1 & 2 \\
Semi critical & 8 & 4 \\
Safe & 3 & 7 \\
Saline & $\mathrm{Nil}$ & $\mathrm{Nil}$ \\
& 17 & 17 \\
\hline
\end{tabular}

(Source: Tamil Nadu State Ground and Surface Water Resources Data Center)

Therefore, in the last five years, the groundwater level in Theni District has increased by nearly $7 \mathrm{~m}$. It is the most important one in groundwater development. The previous studies state about groundwater resources and development. State of Environment Report for Tamil Nadu clearly explained the real situation of Tamil Nadu as the total annual groundwater draft in 2011 due to irrigation was 13.2 bcm (88 per cent) of the net compared to $16.8 \mathrm{bcm}$ (95 per cent) in 2004 (CGWB, 2014).

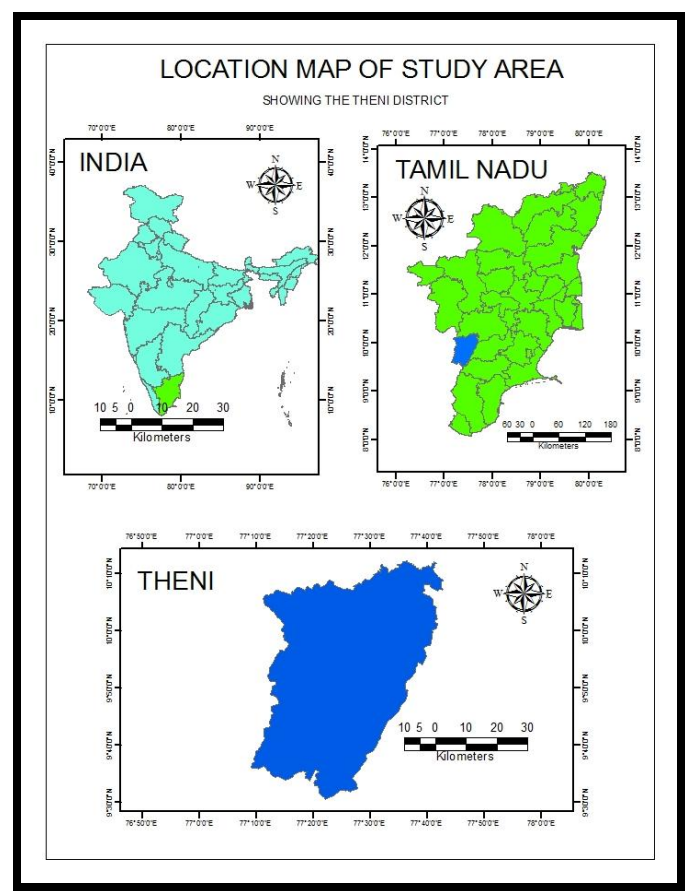

Figure 1. Location Map of Theni District

Dynamic groundwater resources of India states that in Theni district, the Annual groundwater draft due to irrigation was 29341.10 ham and groundwater availability for future irrigation was 8445.72 ham. The district depth to water level is not uniform from 2005 to 2007 and is limited to areas having $2-5$ (m.bgl) meter below ground level. The type of water $107|1-3| 94$ level 2 - 5 (m.bgl) predominates in the study area, having charnockite rock type. Jain and Kumar (2012) analysed the past 100 years of rainfall data in Tamil Nadu and suggested that the rainfall has increased by about 8.5 per cent in the Cauvery river basin and by about 4.4 per cent in the river basins of north Cauvery.

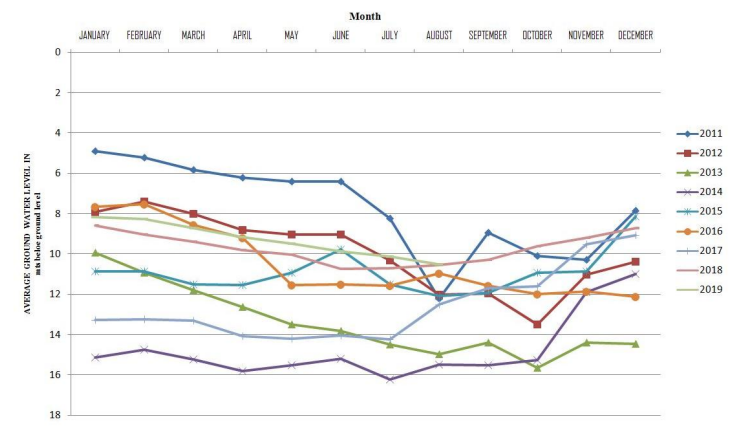

Figure 2. Average Ground water level status

The study further suggests that river basins of south Cauvery have experienced a decline (of about 9.8 per cent) in their annual rainfall. Excellent groundwater potential zone is concentrated in the north-eastern and north-western regions of the district due to the distribution of alluvial plains and agricultural land with high infiltration ability (Magesh et al., 2012).

\section{Comparative Analysis of Rainfall and Groundwater Level}

Rainfall is the primary source for groundwater recharge. Therefore, the comparative analysis between rainfall and groundwater level is a suitable parameter for analysis.

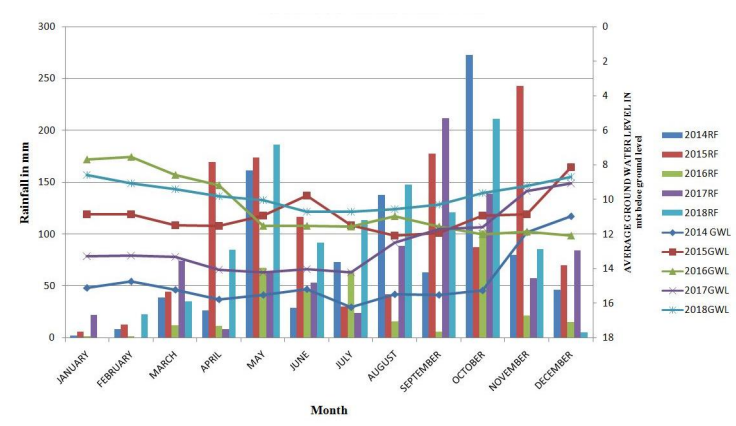

Figure 3. Groundwater level Vs Rainfall

Figure 3 explains the relationship between rainfall and groundwater level of the Theni district from 2014 to 2018. In October 2014, there is a peak rainfall occurred more than $250 \mathrm{~mm}$. So in November 2014, the Groundwater level was observed as a sudden increase from approximately 15 to 12 m below ground level. In November 2015, there is a peak rainfall occurred more than $200 \mathrm{~mm}$. Hence in December 2015, Groundwater level was observed a sudden increase from approximately 11 to $8 \mathrm{~m}$ below ground level. 


\section{Performance Indicator}

In Theni District, there are 17 firkas were categorized based on groundwater extraction. When compared to the 2011 and 2013 data (Figure 4), the Over Exploited Firkas comes down from 29\% to $24 \%$, the Critical Firkas increased from $6 \%$ to $12 \%$, the Semi Critical Firkas decreased from $47 \%$ to $23 \%$, the Safe Firkas increased from $18 \%$ to $41 \%$ and the saline firkas remains zero per cent.

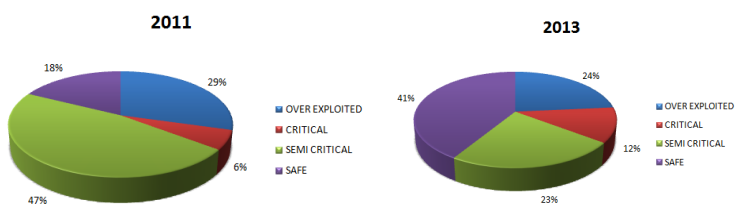

Figure 4. Categorisation of Firkas

In Aundipatti Taluk, Rajasthani Firka was converted from Over Exploited Firka to Critical Firka. In Bodinayakanur Taluk, Kodankipatti and Rasingapuram Firkas were converted from Semi Critical into Safe Firkas. Therefore, Bodinayakanur Taluk became a Safe Firkas Taluk.

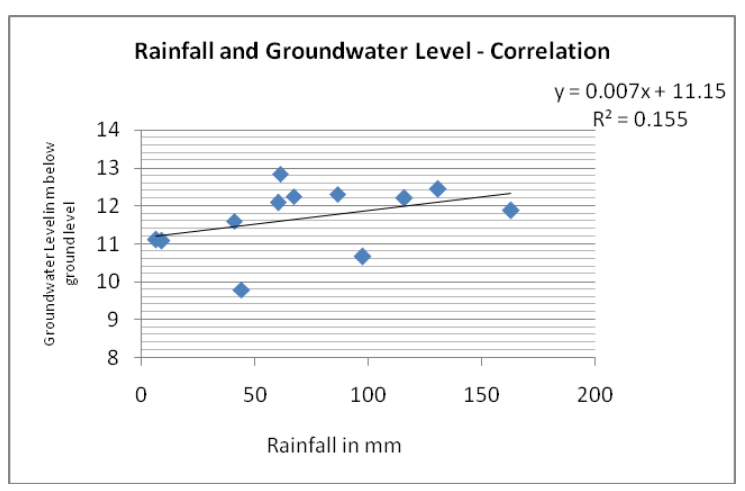

Figure 5. Correlation between rainfall and groundwater level

In Periyakulam and Theni Taluk, no change in the Firkas category remains the same as in 2011. So much more groundwater development is required in those Taluks. In Uthamapalayam Taluk, Cumbum Firka was converted from Semi Critical into Safe. Maintaining safe Firkas as safe is the most critical management criteria.

\section{Statistical correlation between rainfall and groundwater level}

The statistical correlation between the rainfall and groundwater level (2014-2018) of the Theni district is presented (Figure 5). The correlation equation is $y=0.007 x+11.15$ and the $R^{2}$ value is 0.155 . The analysis reveals that there is a poor correlation between the rainfall and groundwater level. Hence the groundwater recharge depends not only with rainfall but also with soil characteristics, slope, groundwater pumping, etc.

\section{CONCLUSION}

The Groundwater level of the Theni district has improved from 2014 to 2019 . Therefore, it is a good sign for groundwater development observed in that district. The alteration of Firkas are due to the construction of Artificial Recharge structures such as Check dams, Recharge wells, Recharge shafts, Percolation ponds, etc was constructed in the Over Exploited Firkas and leading to increase the green cover over the Theni district. Due to the sustained campaign undertaken since 2003, and the efforts of all the stakeholders involved, there has been a considerable increase in the groundwater level as a response strategy.

\section{REFERENCES}

Bhagu R.Chahar (2014). Groundwater Hydrology, Tata McGraw Hill.

Buchanan, S. and Triantafilis, J., (2009). Mapping water table depth using geophysical and environmental variables, Groundwater 47(1): 80-96.

District Groundwater Brochure (2008). Theni District, Tamil Nadu, Central Ground Water Board, SECR, Chennai

Chow, V.T., D.R. Maidment and L.W. Mays. (1988). Applied Hydrology, McGraw Hill.

Customized Rainfall Information System (CRIS), Hydromet Division, India Meteorological Department, Ministry of Earth Sciences, Government of India.

District profile, Department of industries and commerce, District Industries Center, Theni District.

Imtiyaz, M. and Rao, D.J.M., (2008). Influence of over exploitation on groundwater ecosystem in hard rock terrain, Proceedings of International Groundwater Conference, March 19-22, Jaipur, India 88.

Jain S K and Kumar V (2012) Trend analysis of rainfall and temperature data for India, Current Science, 102 (1): 37-49.

Kokilavani Sembanan, Panneerselvam.S and Dheebakaran.Ga (2019). Centurial Rainfall Analysis for Drought in Coimbatore City of Tamil Nadu, India, Madras Agricultural Journal, 106(7-9): 484-487.

Magesh NS, Chandrasekar N and John Prince Soundranyagam (2012). Delineation of groundwater potential zones in Theni district, Tamil Nadu, using remote sensing, GIS and MIF techniques, Geoscience Frontiers 3(2): 189-196.

Water Resources Planning, National Water Policy, Ministry of Water Resources, Government of India, 2002.

Nimmi Kuruppath, A. Raviraj, Balaji Kannan and K.M. Sellamuthu (2018). Estimation of Groundwater Recharge Using Water Table Fluctuation Method. Int.J.Curr.Microbiol.App.Sci. 7(10): 3404-3412.

Rana Chatterjee and Raja Ram Purohit (2009). Estimation of replenishable groundwater resources of India and their status of utilization, Current Science, 96(12): 1581-1591. 
Saraf A K, Choudhury P R, Roy B, Sarma B, Vijay S and Choudhury S (2004). GIS based surface hydrological modelling in identification of groundwater recharge zones. International Journal of Remote Sensing, 25(24): 5759-5770.

Sophocleous, M.A. (1991). Combining the soil water balance and water level fluctuation methods to estimate Natural Groundwater recharge: Practical Aspects, Journal of Hydrology, 124 (34): 229-241.
State Ground and Surface Water Resources Data Center, Water Resources Department, Government of Tamil Nadu.

Sukumar.S and Sankar.K (2011). Statistical Study on Pre \& Post Monsoon Variation of Groundwater Level in Theni District, Tamil Nadu - India, International Journal of Environmental Sciences, 1(5): 798-813.

Todd KD and Larry W.Mays(1980). Groundwater Hydrology, $3^{\text {rd }}$ Edition. 